\title{
Partnering Mechanism in Construction: An Empirical Study on the Chinese Construction Industry
}

J. Constr. Engrg. and Mgmt., Volume 132, Issue 3, pp. 217-229 (March 2006)

Wenzhe Tang, ${ }^{1}$ Colin F. Duffield, ${ }^{2}$ and David M. Young ${ }^{3}$

${ }^{1}$ Postdoctoral Fellow, Dept. of Construction Management, Tsinghua Univ., Beijing, 100084, PR China; formerly, Research Engineer, Dept. of Civil and Environmental Engineering, The Univ. of Melbourne, Australia. E-mail: twz@mail.tsinghua.edu.cn ${ }^{2}$ Associate Professor, Dept. of Civil and Environmental Engineering, The Univ. of Melbourne, 3010, Australia. E-mail: colinfd@unimelb.edu.au

${ }^{3}$ Professor, Dept. of Civil and Environmental Engineering, The Univ. of Melbourne, 3010, Australia. E-mail: dmyoung@unimelb.edu.au

(Accepted 22 March 2005)

Partnering and its principles have increasingly been introduced to the construction industry to improve the efficiency of project delivery. However, little research outlines the mechanism behind its application. This paper presents the findings of a study that was conducted to develop and test a partnering model that reveals the relationships between the critical success factors (CSFs) of partnering and demonstrates their importance to construction. With support of data collected from the Chinese construction industry, this study has revealed strong correlations among partnering CSFs, risk management, total quality management (TQM), use of incentives, and project performance. It is concluded that project success is the outcome of the interaction between a variety of techniques, and that partnering, associated with incentives, is a basic management method through which risk management and TQM can be strongly improved. 


\section{University Library}

\section{- $\mathrm{M}$ IIN E R VA A gateway to Melbourne's research publications}

Minerva Access is the Institutional Repository of The University of Melbourne

Author/s:

Tang, WZ;Duffield, CF;Young, DM

Title:

Partnering mechanism in construction: An empirical study on the Chinese construction industry

Date:

2006-03-01

\section{Citation:}

Tang, W. Z., Duffield, C. F. \& Young, D. M. (2006). Partnering mechanism in construction: An empirical study on the Chinese construction industry. Journal of Construction Engineering and Management, 132 (3), pp.217-229. https://doi.org/10.1061/ (ASCE)0733-9364(2006)132:3(217).

Publication Status:

Published

Persistent Link:

http://hdl.handle.net/11343/34258 